\title{
Fraser Syndrome: Two millennia of cryptophthalmos from Pliny the Elder to FRAS, FREM and GRIP: A historical perspective
}

\author{
George R. Fraser \\ Green Templeton College, Oxford, UK \\ Email: fraser.george@gmail.com \\ Received 20 May 2013; revised 21 June 2013; accepted 6 July 2013 \\ Copyright (C) 2013 George R. Fraser. This is an open access article distributed under the Creative Commons Attribution License, \\ which permits unrestricted use, distribution, and reproduction in any medium, provided the original work is properly cited.
}

\begin{abstract}
From its first description in antiquity, the place of cryptophthalmos in the history of medical genetics is briefly set out until, in the twentieth century, this rare constellation of multiple congenital malformations of which cryptophthalmos is the most striking, even though not obligatory, component, was identified as an inherited autosomal recessive condition. It was given the name of Fraser syndrome and mutant alleles of the genes FRAS1, FREM2 and GRIP1 were identified as being responsible for a proportion of cases. In the remainder of cases, it may be supposed that mutant alleles of other genes, as yet unidentified, are responsible. In general, this association of multiple disparate malformations in an autosomal recessive condition may be expected to throw light on important aspects of gene action in embryogenesis. An aspect of medical genetics, which has become important with respect to the condition, is antenatal diagnosis with the prospect of abortion of affected fetuses.
\end{abstract}

Keywords: Cryptophthalmos; Fraser Syndrome;

Blindness; Deafness; Sublethal Genes; Autosomal

Recessive Inheritance

\section{INTRODUCTION}

With reference to the title, Gaius Plinius Secundus (23 to 24 August 79 AD), better known as Pliny the Elder, was an outstanding author, natural philosopher, and naval and military commander who wrote Naturalis Historia [1]. He believed that "true glory consists of doing what deserves to be written, and writing what deserves to be read". As Admiral of the Roman Fleet, he perished in 79 AD trying to help survivors of the eruption of Mount Vesuvius.
In Book VII of his Naturalis Historia, Chapter XII entitled Examples of many who have been very like and resembled one another, begins with the following sentence. In Lepidorum gente tres, intermisso ordine, obducto membrana oculo genitos accepimus (We have heard it stated that three children of a couple belonging to the clan of the Lepidi, have been born, although not in uninterrupted succession, with an eye covered with a membrane of skin). This sentence does not specify whether reference is being made with one eye or both eyes in any of the three sibs.

This observation probably represents an early report of cryptophthalmos (hidden eye behind an unopened eyelid) inherited in an autosomal recessive manner, and it has been mentioned as such by many authors. Thus, Pliny the Elder distilled into one sentence the main features of the condition under discussion, the eye hidden behind unopened eyelids and the familial occurrence within a sibship.

\section{CRYPTOPHTHALMOS BEFORE THE ERA OF GENETIC MEDICINE}

Going fast forward eighteen centuries from the time of Pliny the Elder to 1872, we come to an outstanding description of a case of cryptophthalmos by Zehender and Manz [2] in a six-month old girl. It is in this paper that the term cryptophthalmos (hidden eye), or Kryptophthalmus in German, was first used. It is of interest to note that the mother attributed the misfortune to the fact that a blind cat terrified her by jumping on to her from a fence. Every physician who has dealt with families with handicapped offspring has heard many stories of this nature.

Zehender and Manz [2] first pointed out in 1872 that the malformation is not restricted to the eyes but is generalized. Thus, in their patient (Figure 1), there was an umbilical hernia and the external genitalia were abnor- 
mal. The anal and vesical sphincters showed impaired function. There were variable findings of syndactyly in both hands and both feet.

Zehender and Manz [2] who performed a post mortem examination of the disorganized ocular tissues behind the unopened eyelids, including detailed histology, described the child as a "Monstrum". As long ago as the sixteenth century, however, in his essay Of a Monstrous Child [3], written in 1580, Michel Eyquem de Montaigne (15331592) wrote: Those that we call monsters are not so to God, who sees in the immensity of His work the infinite forms that He has comprehended therein; and it is to be believed that this figure which astonishes us has relation to some other figure of the same kind unknown to man. From His all wisdom nothing but good, common, and regular proceeds, but we do not discern the disposition and relation:

Quod crebro videt, non miratur, etiamsi, cur fiat, nescit. Quod ante non vidit, id, si evenerit, ostentum esse censet. "What he often sees he does not admire, though he be ignorant how it comes to pass. When a thing happens he never saw before, he thinks that it is a portent." -Cicero, De Divin, 2. 22].

Whatever falls out contrary to custom we say is contrary to nature, but nothing, whatever it be, is contrary to her. Let, therefore, this universal and natural reason expel the error and astonishment that novelty brings along with it.

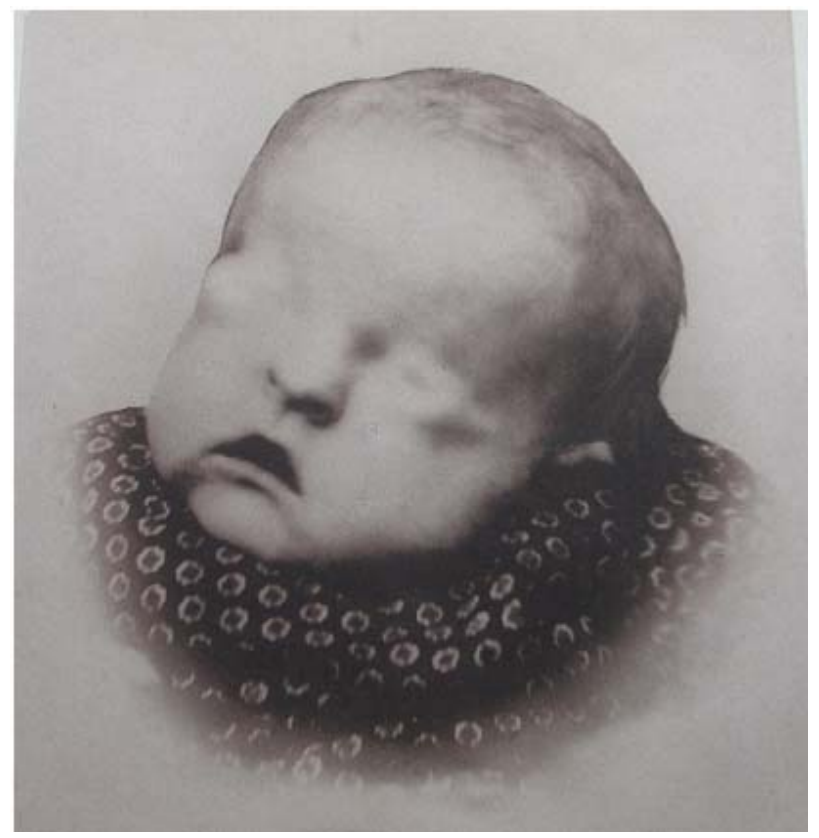

Figure 1. The striking photograph shown here was taken in 1872 , less than fifty years after the advent of photography. The drastic expedient of chloroform anesthesia was employed in order to prepare the child for this photograph, taken seven weeks before the death of the infant at the age of nine months.
In 1902, Golowin wrote a remarkable article [4] on cryptophthalmos occurring in his Moscow practice. He described two cases, the first a healthy 26-year-old married, but childless, peasant, and the second a two-monthold girl who had an affected sister. The man was blind with total cryptophthalmos on the right and partial on the left. He begged the surgeon to cut through the skin covering the right eye, since he found the feel of the eye region and the consequent asymmetry of his face hateful. The surgeon complied with his request; the patient was overjoyed.

Thus, we find in this report that the condition is compatible with healthy survival into adult life and with marriage. We also find the occurrence of the condition in sibs, as first described by Pliny the Elder.

In an extensive review of the literature, Golowin [4] differentiated cryptophthalmos from forms of anophthalmos and microphthalmos. In no case was any functional remnant of the eye present when the eyelids were surgically opened. He included cases with consanguineous parents and mentioned many of the associated malformations which we now know as part of the syndrome (syndactyly, gender ambiguities, abnormal development of the nose and auricles, laryngeal stenosis and ossification defects in the bones of the skull). He determined that the cryptophthalmos could be bilateral or unilateral and that in some unilateral cases the other eye was entirely normal.

Avižonis in 1928 [5] described a case and wrote a comprehensive review of the literature of the cryptophthalmos syndrome which had already been well delineated by that time. Although many familial cases had been described, there had not been any mention of the possibility of the hereditary nature of the condition.

Throughout this period, cases of cryptophthalmos were reported not only in human beings but also in pheasants, rabbits, pigeons, and chickens. In 1906, at a Japanese Ophthalmological Congress, Asayama [6] reported the condition in eight out of 50 inbred mice. His findings can be regarded as the first recorded instance of the blebbing mutants in mice, which played such a large part in unravelling the molecular biology of Fraser syndrome a century later.

To place the cryptophthalmos syndrome in its chronological context within the wider historical perspective of the significance of genetics to medicine, the paper of Zehender and Manz in 1872 [2] was almost contemporaneous with the description by Langdon Down in 1866 [7] of what he called "mongolism", a term now superseded by "the Down syndrome". In his paper, Langdon Down wrote that his findings, leading to his calling the disease "mongolism", furnished "some arguments in favor of the unity of the human species". Even though his reasoning was somewhat unorthodox in that he invoked the hypothesis that disease is able to break down 
the barrier between racial divisions so as to simulate closely the features of the members of a division other than that of the patient, his conclusion echoes the sentiment, expressed so beautifully and so concisely in the poetry and music of Schiller and Beethoven, Alle Menschen werden Brüder or All mankind will be brothers. Almost a century after the paper of Langdon Down, in 1959, Lejeune, Gautier and Turpin [8] discovered the trisomy of chromosome 21, which characterizes the Down syndrome.

It should be noted that the seminal work of Abbot Johann Gregor Mendel on peas, published in 1866 [9], was proceeding in a quiet monastery garden not long before the discoveries in 1872 of Zehender and Manz [2] with respect to cryptophthalmos, even though these authors could not, of course, have conceived of the vast significance of Mendel's work in connection with the future elucidation of the chromosomal theory of heredity, nor have divined the role of heredity by the operation of autosomal recessive inheritance in the causation of the condition.

It should also be noted that the paper of Langdon Down [7] with respect to the Down syndrome which is associated with a chromosomal anomaly, was published in the same year (1866) as the work of Mendel [9], although, of course, Langdon Down could not have been aware of the significance of Mendel's work in connection with his description of "mongolism".

These discoveries [2,7,9], published within a brief span of years between 1866 and 1872, contributed in a remarkable manner to presaging the advances of the era of genetic medicine.

\section{CRYPTOPHTHALMOS IN THE ERA OF GENETIC MEDICINE}

In 1962, I wrote a review of the genetic load of our species, or the deficit expressed in terms of disease and premature death caused by less than optimal genotypes [10]. This is a 28-page paper, and just half a page was devoted to two pairs of sisters who suffered from the "syndrome of cryptophthalmos" whom I had seen during my studies of profound deafness in children over the preceding five years. Thus, the main features of the "syndrome of cryptophthalmos" were described in this very short section of a long paper dealing with the load of lethal and detrimental gene mutations.

This short section was preceded by the following paragraph based on large studies in Japan, sponsored by the Atomic Bomb Casualty Commission.

There was a significant increase in major congenital abnormalities amongst the offspring of first cousin matings. This suggests that recessive inheritance plays some part in the causation of these major congenital abnormalities, and the tendency is especially marked when the complex anomalies were considered.

I suggested for the first time that the "syndrome of cryptophthalmos" was an autosomal recessive condition. I listed the following as malformations forming part of the syndrome-cryptophthalmos; absent or malformed lachrymal ducts; middle and outer ear malformations; high palate; cleavage along the midplane of nares and tongue; hypertelorism; laryngeal stenosis; syndactyly; wide separation of symphysis pubis; displacement of umbilicus and nipples; primitive mesentery of small bowel; maldeveloped kidneys; fusion of labia and enlargement of the clitoris; bicornuate uterus and malformed Fallopian tubes. Many other malformations have been added to this list since 1962.

In each of the sibships which I described, one sister was stillborn and the other survived. One of the two surviving girls, Michele S, had fully developed bilateral cryptophthalmos. When I first met her in 1960 at the age of five, she was not only blind but also profoundly deaf in association with malformations of the outer and middle ears. The other surviving girl, Carol D, did not show the characteristic feature of cryptophthalmos but could be identified as a case of Fraser syndrome because she showed many of the other components of the condition and because she had a fully affected stillborn sib. She provides a striking illustration of the fact that every component of the syndrome is widely variable in its manifestations, giving rise to the anomalous diagnostic label of "cryptophthalmos syndrome without cryptophthalmos". The condition did not give rise to any educational handicap in the case of Carol D. Children without educational handicap have been described in whom the cryptophthalmos was unilateral, the other eye being entirely normal [11].

Michele S was first ascertained in 1960 during my studies of 3535 individuals with profound childhood deafness between 1957 and 1967; she was ascertained for a second time in 1964 during the course of my studies of the causes of blindness in 776 children between 1963 and 1965. These studies have been comprehensively described in two books [12,13]; both books contain details about Michele.

It should be noted that the mental ability of Michele is potentially normal. In reviews of the pleiotropic nature of this syndrome leading to widely variable degrees of manifestation in each of the organs which can be involved, it is accepted that the mental status can be normal, but this normality may, of course, be cloaked by sensory deprivation, especially when both eyes and, in addition, hearing, are involved, as in Michele's case. In contrast to Michele, Carol D who is neither deaf nor blind, has enjoyed normal mental development.

Since severely affected individuals with this condition are stillborn or do not survive infancy, the gene concerned may be regarded as being sublethal. The concept 
of sublethal genes was extensively discussed in 1955 by Hadorn [14] who coined the term "Durchbrenner" (escapers) for experimental animals who survive even though they are homozygous for autosomal recessive sublethal genes responsible for multiple malformations which are often incompatible with survival beyond infancy. Both Michele S and Carol D may be regarded as Durchbrenner in this sense although Michele is far more seriously affected than Carol. The critical threshold with respect to failure to survive is often associated with extreme degrees of bilateral renal hypoplasia or with bilateral renal aplasia, manifested in both stillborn sibs of the two girls.

How did these two paragraphs, a very small part of a long paper on the genetic load [10], written 90 years after the outstanding paper of Zehender and Manz [1], lead to the assignment of my name as an eponym with respect to the Fraser syndrome?

In 1963, Victor McKusick had sent me catalogs in manuscript form of X-linked and autosomal recessive conditions, asking for comments and using my name as an eponym with respect to the cryptophthalmos syndrome. I went through these draft catalogs and sent my comments to Victor; I quote one of these comments:

I am flattered by the eponym (Fraser syndrome). However, copious references to cryptophthalmos (as you indicate on pages 6 - 7 of your addenda) are to be found in the literature and the presence of many other malformations has been noted.

Nevertheless, when these manuscript catalogs came to fruition in 1966 in the first published edition of the catalogs as we know them today [15], the eponym was to be found there. It took some time for it to be generally adopted. In 1983, Buyse [16] wrote in an editorial comment on the anomalous phenomenon that the diagnosis of the "cryptophthalmos syndrome" was being made in individuals who did not in fact manifest cryptophthalmos among their multiple malformations: " $D r$ Feingold brings up an important issue of nomenclature when he points out the difficulty of diagnosing a condition that is named after a clinical feature not present in the particular patient with that diagnosis... Perhaps, cryptophthalmos syndrome should be called Fraser syndrome, an eponymic designation under which it is already known. However, I do not believe this would solve the basic issue of understanding the pathogenesis of the cryptophthalmos syndrome..."

In 1986, two decades after McKusick’s initial assignment of my name as an eponym, in a letter to the editor of Clinical Genetics, entitled Cryptophthamos-syndactyly syndrome without cryptophthalmos, Meinecke [17] wrote: “...it has now been proved by an adequately large number of cases that cryptophthalmos is not an obligatory feature of the Fraser syndrome. However, since the des- ignation 'cryptophthalmos syndrome' might be prejudicial in implying that cryptophthalmos is part of the syndrome, the eponymic designation, 'Fraser syndrome', is perhaps to be preferred".

I had first been told about Michele S at a small hospital unit for deaf-blind and ineducable children. She had been sent home as being unmanageable and, as part of my studies of profound childhood deafness I went to see her at her home in rural Essex in March 1960.

Her mother has written a small unpublished book about Michele's upbringing; this is how she describes our first meeting.

Henry and I were out in the greenhouse in the garden. Suddenly two men carrying black briefcases came towards us. At first I thought they were Jehovah's Witnesses but they introduced themselves as doctors from the Nuffield Hospital, Grays Inn Road, London. One said, "We hear that you have a little girl who has an ear defect. We think she might be deaf and would like to see her. Dr Williams passed your letter on to us".

More than four decades later, when I read the book, I tried to persuade Mrs. S that the two Jehovah's Witnesses had been just one person, to wit, I myself. Michele was five years old at the time of our first meeting. I spent the afternoon with her and with her parents. Michele behaved in a very wild manner, almost like a feral child, reacting with a terrified scream to any attempted approach. I noticed that she seemed very fond of a large alarm clock which she continually pressed to her forehead. I suspected that there might be a conductive element to her deafness. As part of my studies of deafness in Oxford, I had been seeing groups of children with malformations of the outer and middle ears. I was collaborating in this study with an otorhinolaryngologist, Gavin Livingstone, who was interested in improving the hearing of these children by reconstructing the outer and middle ear. Gavin Livingstone agreed to see Michele; he reconstructed her outer and middle ears, and Michele began to hear for the first time at the age of six years. By the time she was nine, she was keeping up with the children at Condover Hall, a school for the deaf and blind. She was able to communicate with other children and with members of the staff, as I was able to confirm when I saw her for the second time at Condover Hall in 1964 during the course of my studies of the causes of blindness in children.

She has been well looked after for many years in a home run by a charity called Sense, where I was able to meet her for the last time at the age of 51 years in 2005, 45 years after our first meeting.

I shall let Michele's mother continue Michele's story a few months after the operations by Gavin Livingstone on her ears in 1960.

It was at this point Mr Livingstone declared, "This 
child must be educated. There is now a new unit which has been opened by the Royal National Institute for the Blind in the small village of Condover, Shropshire. It is a unit for blind and deaf children and is called, 'Pathways'. The school has been built in the grounds of a large mansion, Condover Hall. I will get in touch with them and Michele must have an assessment. You will hear further about it."

Was I dreaming? Not only could our child hear and was beginning to use the English language but there was a hope she would receive an education. Imagine how Henry and I felt? We were struck dumb with disbelief. We had just gone through six years of being told Michele was uneducable and so mentally handicapped she would never talk and now realized the diagnosis was wrong. She had been totally deaf and now had some useful hearing.

In 1964, Michele's mother wrote me a letter after I had seen her daughter at Condover Hall. I had asked her to fill in a form which I was using during the course of my studies of the causes of blindness in children:

\section{Dear Dr Fraser}

I hope that the form has been filled in satisfactorily and that some help may be gained from it.

I would like to take this opportunity of thanking you for being instrumental in the discovery of Michele's deafness. The operation proved very successful. She is now talking very well, is learning Braille and figure work, and is rapidly becoming a normal blind child.

Thank you for your interest in her.

Yours sincerely

Later in 1964, on 27 October, Michele's mother wrote to me again:

\section{Dear Dr Fraser}

We have returned from a four-day assessment at Condover with Michele.

They are most impressed with her and the things she manages for herself and are taking her for training in the New Year until her speech is fluent when they will pass her to Blind School. They think once she settles they will do quite a lot with her. Her vocabulary increases daily and she always remembers, though perhaps she hasn't touched the article, or said the word, for weeks.

The three of us will always be deeply grateful to you, for making the trip to Great Baddow to see Michele, and we feel that now she should go ahead. Condover is certainly a wonderful place...

Thank you for all you have done for us and for the interest you have shown in Michele.

Yours sincerely

Michele has lived a life which I believe to have been much more tolerable than it would have been without any hearing. Perhaps this small contribution to the improvement in the quality of the life of this girl represents a greater achievement than that of my name becoming attached to a syndrome, or even, in abbreviated form as FRAS1 to a gene. Michele was initially thought to be a boy because of indeterminate genitalia; sex chromatin studies at the age of one year showed an XX karyotype, and she was then raised as a girl.

A breakthrough occurred in the study of the Fraser syndrome with the publication of two papers by the late Robin Winter in 1988 and 1990 [18,19]. The first of these papers was a wide-ranging review of mouse/human homologies with respect to hereditary malformation syndromes. In this paper, two mouse mutants, bl-blebbed and my-myencephalic blebs, were suggested as homologs for human mutants giving rise to Fraser syndrome. The second paper related specifically to this possibility and raised the very important point that subepidermal blebs or blisters could play an important role during embryonic development in the pathogenesis of the malformations seen in the Fraser syndrome.

Robin Winter pointed out that this suggestion of homology might be helpful for three reasons.

1) Providing clues for the genetic mapping of Fraser syndrome by reference to mouse/human homology of chromosome segments.

2) It might point to genetic heterogeneity in view of the fact that at that time three nonallelic mouse mutants had been characterized that produce similar phenotypes.

3) It might provide an additional ultrasound marker when attempting first trimester prenatal diagnosis, namely subepidermal blebs.

All these three far-seeing predictions have been confirmed during the more than twenty years which have elapsed since the publication of this paper.

Thus, in 1994, Darling and Gossler [20] wrote a review entitled A mouse model for Fraser syndrome. They stated that the first mouse bleb mutants were described by Little and Bagg in 1924 [21], but, as mentioned above, Asayama in Japan in 1906 [6] had already described eight cases of cryptophthalmos among 50 inbred mice.

Chromosome 4 then became the target for the location of the gene responsible for the Fraser syndrome; some inconclusive linkage studies were carried out before Professor Peter Scambler accepted a PhD student called Lesley McGregor towards the end of the nineteen-nineties, to work on the topic in the Molecular Medicine Unit at the Institute of Child Health, University College London.

I had reached the age for obligatory retirement in 1997 and I was not aware of these studies. During this period, I was attending very few professional meetings; it was the merest chance, fate, serendipity, providence, call it what you will, which took me to Birmingham for a meeting of the European Society of Human Genetics in May 2003, the main practical consideration being that Bir- 
mingham is near my home.

\section{CRYPTOPHTHALMOS AND MOLECULAR MEDICINE}

In the opening address, I learned that Professor Scambler was going to talk three days later in the Late-Breaking Research Session, a talk not previously announced, about the Fraser syndrome. And it was in that session that I first met Peter Scambler and first learned that a mutant allele of a gene named FRAS1, mapped to chromosome 4 (4q21), was responsible for the Fraser/cryptophthalmos syndrome.

Several articles were published between 2003 and 2005 in Nature Genetics, Proceedings of the National Academy of Science and Human Molecular Genetics by Peter Scambler, Ian Smyth and their groups, together with collaborators in Greece and other countries, concerning the genetics and molecular biology of the syndrome. The first of these papers is a condensed version of Lesley McGregor's PhD thesis [22]. Fraser syndrome, an autosomal recessive condition, was shown to be caused by a mutation in a gene designated as FRAS1 and located on chromosome 4. This paper was coupled with another [23] showing that the corresponding syndrome in $\mathrm{bl} / \mathrm{bl}$ blebbed mice was caused by a mutation in a homologous gene (FRAS1) on chromosome 5 of the mouse.

This gene, FRAS1, and its homologs exist in Man, in the mouse, and, as can be confirmed on the ensembl website (http://www.ensembl.org), in other vertebrate species. It is one of a group of genes controlling the production of proteins which are required for the adhesion between epidermal basement membrane and the underlying dermal connective tissues during embryonic development. These proteins have also been shown to play a crucial role in the initiation and development of the kidney including assuring the integrity of the renal glomeruli [24] and they may modulate cell signalling.

This group of genes includes FRAS1 on chromosome 4, FREM1 (FREM standing for "FRAS1-related extracellular matrix") on chromosome 9, FREM2 on chromosome 13, FREM3 on chromosome 4, and GRIP1 (GRIP stands for "glutamate receptor interacting protein") on chromosome 12. All these genes have been identified in most of the vertebrate species whose genomes have been studied and recorded on the ensembl website

(http://www.ensembl.org). Mutations giving rise to the Fraser syndrome have been found in FRAS1, FREM2 and GRIP1 [22,25,26].

Slavotinek and Tifft [27] wrote an extensive article in 2002 reviewing the literature of Fraser syndrome and cryptophthalmos. A review article by Smyth and Scambler [28] appeared in 2005 concerning the genetics and molecular biology of the syndrome, and of its homologs in the mouse. Two papers by van Haelst and collabora- tors in 2007 and 2008 [25,29] summarized the knowledge then available about the Fraser syndrome as a result of the study of 59 cases in 33 families. In 2011, a paper was published [30] reviewing two autosomal recessive syndromes which subsumed components of the Fraser syndrome. In this paper, Manitoba-oculo-tricho-anal (MOTA) syndrome and bifid nose, renal agenesis and anorectal malformations (BNAR) syndrome were found to be associated with mutations of the FREM1 gene.

It should be noted that the disabilities associated with the fully expressed form of Fraser syndrome are even more severe than those associated with the Down syndrome, and yet there are families who are bringing up such children in an atmosphere of harmony and happiness. Thus, recently, antenatal diagnosis of a fully affected female fetus was not followed by an abortion but rather by surgery involving the trachea, in order to relieve the effects of laryngeal malformation-not gene therapy in utero as yet, but at least surgical intervention in fetal life leading to the survival of a fetus suffering from a potentially fatal autosomal recessive disease [31].

Thus, the Fraser syndrome can manifest itself at the very beginning of life in the fetus; it can also be present throughout the entire gamut of years until extreme old age. Although the prognosis for survival in individuals born with this condition is, in general, poor, a case has been reported [32] of a woman surviving to the age of 96 years when she died as the result of an accident. This lady is truly a "Durchbrenner" (escaper) in the sense used by Hadorn (1955) in the book [14] which I have already mentioned.

\section{ACKNOWLEDGEMENTS}

I acknowledge with gratitude my contacts with two human beings who were unfortunate in the lottery of the genes. Florina B (24/3/99 to 20/2/2008) and Michele S (born 16/6/1954). These contacts provided me with moving experiences [33].

\section{REFERENCES}

[1] Gaius Plinius Secundus (Pliny the Elder) (77-79) Naturalis historia.

[2] Zehender, W. and Manz (1872) Eine missgeburt mit hautüberwachsenen augen oder kryptophthalmus. Klinische Monatsblätter für Augenheilkunde, 4, 225-234.

[3] Michel Eyquem de Montaigne (1580) Of a monstrous child. Essays (Second Book, 30).

[4] Golowin, S. (1902) Beiträge zur anatomie und pathogenese des kryptophthalmus congenitus. Zeitschrift für Augenheilkunde, 8,175-212. doi:10.1159/000289955

[5] Avižonis, P. (1928) Über kryptophthalmus congenitus. Klinische Monatsblätter für Augenheilkunde, 64, 240-256. doi:10.1159/000296483

[6] Asayama (1906) Vererbung von kryptophthalmus. Klinis- 
che Monatsblätter für Augenheilkunde, 44, 346

[7] Down, J.H.L. (1866) Observations on an ethnic classification of idiots. London Hospital Records, 3, 259-262.

[8] Lejeune, J., Gautier, M. and Turpin, R. (1959) Etude des chromosomes somatiques de neuf enfants mongoliens. Comptes Rendus Hebdomadaires des Séances de l'Académie des Sciences (Paris), 248, 1721-1722.

[9] Mendel, G. (1866) Versuche über pflanzen-hybriden. Verhandlungen des Naturforschenden Vereines, Abhandlungen, Brünn, 4, 3-47.

[10] Fraser, G.R. (1962) Our genetical "load”. A review of some aspects of genetical variation. Annals of Human Genetics, 25, 38-414. doi:10.1111/j.1469-1809.1962.tb01774.x

[11] Sinclair, W. (1918) A case of cryptophthalmos. Transactions of the Ophthalmological Society UK, 38, 142-144.

[12] Fraser, G.R. and Friedmann, A.I. (1967) The causes of blindness in childhood. A study of 776 children with severe visual handicaps (with preface by L. S. Penrose). Johns Hopkins Press, Baltimore.

[13] Fraser, G.R. (1976) The causes of profound deafness in childhood. A study of 3535 individuals with severe hearing loss present at birth or of childhood onset (with foreword by V. A. McKusick). Johns Hopkins University Press, Baltimore and London.

[14] Hadorn, E. (1955) Letalfaktoren in ihrer bedeutung für erbpathologie und genphysiologie der entwicklung. Thieme, Stuttgart.

[15] McKusick, V.A. (1966) Mendelian inheritance in man: Catalogs of autosomal dominant, autosomal recessive and X-linked phenotypes. Johns Hopkins Press, Baltimore.

[16] Buyse, M.L. (1983) Editorial comment. Journal of Clinical Dysmorphology, 1, 32.

[17] Meinecke, P. (1986) Cryptophthalmos-syndactyly syndrome without cryptophthalmos. Clinical Genetics, 30, 527-528. doi:10.1111/j.1399-0004.1986.tb01923.x

[18] Winter, R.M. (1988) Malformation syndromes: A review of mouse/human homology. Journal of Medical Genetics, 25, 480-487. doi:10.1136/jmg.25.7.480

[19] Winter, R.M. (1990) Fraser syndrome and mouse "bleb” mutants. Clinical Genetics, 37, 494-495. doi:10.1111/j.1399-0004.1990.tb03539.x

[20] Darling, S.M. and Gossler A. (1994) A mouse model for Fraser syndrome. Clinical Dysmorphology, 3, 91-95. doi:10.1097/00019605-199404000-00001

[21] Little, C.C. and Bagg H.J. (1924) The occurrence of four inheritable morphological variations in mice and their possible relationship to treatment with X-rays. Journal of Experimental Zoology, 41, 45-91. doi:10.1002/jez.1400410106

[22] McGregor, L., Makela, V., Darling, S.M., Vrontou, S., Chalepakis, G., Roberts, C., et al. (2003) Fraser syndrome and mouse blebbed phenotype caused by mutations in FRAS1/Fras1 encoding a putative extracellular matrix protein. Nature Genetics, 34, 203-208.

\section{doi:10.1038/ng1142}

[23] Vrontou, S., Petrou, P., Meyer, B.I., Galanopoulos, V.K., Imai, K., Yanagi, M., et al. (2003) Fras1 deficiency results in cryptophthalmos, renal agenesis and blebbed phenotype in mice. Nature Genetics, 34, 209-214. doi:/10.1038/ng1168

[24] Pitera, J.E., Scambler, P.J. and Woolf, A.S. (2008) Fras1, a basement membrane-associated protein mutated in Fraser syndrome, mediates both the initiation of the mammalian kidney and the integrity of renal glomeruli. $\mathrm{Hu}$ man Molecular Genetics, 17, 3953-3964. doi:10.1093/hmg/ddn297

[25] van Haelst, M.M., Maiburg, M, Baujat, G, Jadeja, S, Monti, E., Bland, E., et al. (2008) Molecular study of 33 families with Fraser syndrome: New data and mutation review. American Journal of Medical Genetics Part A, 146A, 2252-2257. doi:10.1002/ajmg.a.32440

[26] Vogel, M.J., van Zon, P., Brueton, L., van Gijzen, M., van Tuil, M.C., Cox, P., et al. (2012) Mutations in GRIP1 cause Fraser syndrome. Journal of Medical Genetics, 49, 303-306. doi:10.1136/jmedgenet-2011-100590

[27] Slavotinek, A.M. and Tifft, C.J. (2002) Fraser syndrome and cryptophthalmos: Review of the diagnostic criteria and evidence for phenotypic modules in complex malformation syndromes. Journal of Medical Genetics, 39, 623-633. doi:10.1136/jmg.39.9.623

[28] Smyth, I. and Scambler, P.J. (2005) The genetics of Fraser syndrome and the blebs mouse mutants. Human Molecular Genetics, 14, R269-R274. doi:10.1093/hmg/ddi262

[29] van Haelst, M.M., Scambler, P.J., Fraser Syndrome Collaborative Group and Hennekam, R.C.M. (2007) Fraser syndrome: A clinical study of 59 cases and evaluation of diagnostic criteria. American Journal of Medical Genetics Part A, 143A, 3194-3203. doi:10.1002/ajmg.a.31951

[30] Slavotinek, A.M., Baranzini, S.E., Schanze, D., LabelleDumais, C., Short, K.M., Chao, R., et al. (2011) Manitoba-oculo-tricho-anal (MOTA) syndrome is caused by mutations in FREM1. Journal of Medical Genetics, 48, 375-382. doi:10.1136/jmg.2011.089631

[31] Kohl, T., Hering, R., Bauriedel, G., van de Vondel. P., Heep, A., Keiner, S., et al. (2006) Percutaneous fetoscopic and ultrasound-guided decompression of the fetal trachea permits normalization of fetal hemodynamics in a human fetus with Fraser syndrome and congenital high airway obstruction syndrome (CHAOS) from laryngeal atresia. Ultrasound in Obstetrics and Gynecology, 27, 8488. doi:10.1002/uog.1974

[32] Impallomeni, M., Subramanian, D., Mahmood, N. and Illes, J. (2006) Fraser syndrome in a 96-year-old female. Age and Ageing, 35, 642-643. doi:10.1093/ageing/afl109

[33] Yap-Todos, E. and Yap, D. (2007) Michele, Florina, and George Fraser: The cryptophthalmos story at the human level. In: Mayo, O. and Leach, C., Eds., Fifty Years of Human Genetics: A Festschrift and Liber Amicorum to Celebrate the Life and Work of George Robert Fraser. Wakefield Press, Kent Town, 299-308. 